\title{
PERANCANGAN PRODUK RAK SENJATA TEATRIKAL UNTUK KOMUNITAS ROODE BRUG SOERABAIA
}

\author{
Juanita Priscilla ${ }^{1)}$, Hoo, Leony Gracia Budi Saputra ${ }^{2)}$ \\ ${ }^{1}$ Program Studi Desain Interior, Universitas Kristen Petra \\ email: juanitapriscill21@gmail.com \\ ${ }^{2}$ Program Studi Desain Interior, Universitas Kristen Petra \\ email: leony.gracia.8898@gmail.com
}

\begin{abstract}
Surabaya is the city of Heroes where the war between people of Surabaya and colonial invaders happened in order to defend the independence of Indonesia. This certainly make a huge impact for the historical stories that until now we often hear since we were studying in elementary school. However, history is slowly forgotten and thus make the emergence of many efforts appear in order to maintaining it. Efforts to preserve history began to be carried out by many communities that spread all around Indonesia and one of them in Surabaya. Roode Brug Soerabaia, a historical community with its vision of bridging the past to the present, begins to preserve history in a variety of interesting ways. Their activities include theatrical and visits to historic buildings and work together to clean buildings that are no longer maintained. In order to fulfill their needs, especially theatrical, a product design was made that could help in storing theatrical property especially for the weapons property they used. The design of this product is intended to make them more enthusiastic in preserving Surabaya's history so that it is not forgotten and can attract the attention of young people nowadays.
\end{abstract}

Keywords: product, community, historical.

\section{PENDAHULUAN}

Sejarah dalam Kamus Besar Bahasa Indonesia yaitu asal-usul (keturunan) silsilah, kejadian dan peristiwa yang terjadi pada masa lampau; riwayat; tambo: cerita, pengetahuan atau uraian tentang peristiwa dan kejadian yang benar-benar terjadi dalam masa lampau; ilmu sejarah. Sejarah berasal dari bahasa Arab "syajara", yang berarti "terjadi". "syajaratun" (baca: syajarah) artinya pohon kayu. Makna dari pohon kayu yaitu ada perkembangan dari sebuah peristiwa yang terjadi dalam suatu kesinambungan (kontinuitas). Seseorang yang mendalami ilmu sejarah tentu berkaitan dengan cerita, silsilah, riwayat dan asal usul tentang seseorang atau kejadian.

Sejarah yang diartikan dalam bahasa Inggris yakni "history", yang berasal dari bahasa Yunani Kuno "historia" (baca: istoria) yang berarti belajar dengan cara bertanya-tanya. Kemudian kata ini diartikan sebagai pertelaan mengenai gejala-gejala (terutama hal mengenai manusia) dalam urusan kronologis (Sjamsuddin, 1996).

Sejarah tidak terlepas dari kisah peperangan antara rakyat Indonesia melawan para penjajah yang datang ke Indonesia. Kisah sejarah ini terus diceritakan dari mulut ke mulut berdasarkan hasil temuan yang dipublikasikan agar semua rakyat dapat mendengar dan mengetahui kebenaran yang telah terjadi pada masa lampau.

Perkembangan teknologi di era masa kini berdampak pada perkembangan berbagai bidang lainnya, salah satunya pada bidang infrastruktur. Perkembangan infrastruktur tentu ada sisi positifnya seperti dalam meningkatkan perekonomian negara. Namun, sisi negatifnya berdampak pada hilangnya bangunan-bangunan bersejarah di kota-kota besar yang infrastrukturnya berkembang cukup pesat. Ironisnya bangunan sejarah mulai hancur rata dengan tanah atau berganti rupa menjadi pusat perbelanjaan atau bangunan baru lainnya.

Perkembangan teknologi juga mengurangi kepekaan yang ada dalam diri para generasi milenial terhadap sejarah yang ada. Urgensi di dalam pemeliharaan dan pelestarian sejarah mulai dilakukan oleh aktivis-aktivis sejarah di berbagai kota dan daerah. Para aktivis yang memiliki kesamaan tujuan dalam bidang sejarah ini kemudian membentuk sebuah perkumpulan komunitas. Komunitas adalah sekelompok orang yang saling peduli satu sama lain lebih dari yang seharusnya, dimana dalam sebuah komunitas terjadi relasi pribadi yang erat antara para anggota komunitas tersebut karena adanya kesamaan interest atau values (Kertajaya, 2008). Komunitas 
sejarah merupakan sebuah kelompok sosial, dimana anggotanya mempunyai ketertarikan yang sama yaitu dalam bidang sejarah dan mempunyai visi yang perlu dicapai dalam komunitas. Salah satunya terdapat di Surabaya, sebuah kota yang dikenal sebagai Kota Pahlawan tentu bukanlah sebuah predikat asal-asalan, namun ada alasan kuat di belakangnya yakni setiap sudut di kota Surabaya ini menyimpan memori heroisme para rakyat Surabaya.

Komunitas pemelihara sejarah di Surabaya dikenal dengan nama Roode Brug Soerabaia yang berarti "Jembatan Merah Surabaya". Komunitas ini mempunyai sebuah visi yaitu ingin menjembatani masa lalu ke masa sekarang. Komunitas yang berperan dalam pelestarian sejarah ini, melakukan berbagai aktivitas mulai dari melakukan teatrikal perjuangan, mendatangi veteran-veteran zaman peperangan dahulu, mengadakan sesi sharing dan diskusi, berkunjung ke lokasi-lokasi bangunan bersejarah, serta bergotong royong dalam membersihkan bangunan sejarah yang tertutupi oleh tanaman liar dan sudah tidak terawat lagi. Kegiatan ini dilakukan dengan satu tujuan yaitu agar sejarah tidak terlupakan dan terus ada dalam benak generasi sekarang hingga generasi selanjutnya.

Pada saat melakukan kegiatan teatrikal, komunitas ini tentunya membutuhkan properti untuk tampil, antara lain seperti senjata, baju perang, karung goni, dan masih banyak lagi. Permasalahan yang ada pada komunitas ini yaitu minimnya ruang penyimpanan yang dimiliki oleh mereka. Sebagai peneliti yang menekuni bidang desain interior, permasalahan ini tentu membutuhkan sebuah solusi khususnya dalam hal produk. Produk merupakan sebuah benda hasil karya keteknikan, yaitu dimulai dari hasil perancangan, kemudian pembuatan dan kegiatan lain yang bersangkutan. Perancangan produk merupa-kan sebuah proses di dalam pembuatan produk yang dimulai dengan pemikiran manusia tentang kebutuhan yang ada. Berdasarkan dengan pembuatan konsep awal dari hasil pemikiran tersebut, selanjutnya masuk dalam tahap perancangan, tahap pengembangan, tahap penyempurnaan produk, dan tahap pendistribusian produk (Harsokoesoemo, 2004). Oleh sebab itu, tujuan dari jurnal ini yaitu ingin menciptakan sebuah produk berupa rak display dan penyimpanan portable untuk menyimpan properti teatrikal dan mudah untuk dipindah-pindahkan sesuai dengan kebutuhan dari komunitas.

\section{KAJIAN LITERATUR}

\section{A. Furnitur}

Furnitur berkontribusi sebagai pemenuhan visual dalam sebuah ruang interior. Visual dalam sebuah furnitur yang dimaksud adalah pengaruh bentuk, garis, warna, tekstur, dan skala masing-masing benda maupun pengaturan spasialnya. Pemilihan perabot yang baik dan aman adalah perabot yang awet, tidak mudah mengelupas, tidak mudah terbakar, mudah dibersihkan, tidak beracun atau menimbulkan reaksi kimia yang berbahaya (Ching, 2002).

\section{B. Ergonomi}

Istilah ergonomi berasal dari bahasa Latin yaitu "ergon" (kerja) dan "nomos" (hukum alam). Ergonomi merupakan sebuah ilmu studi tentang aspekaspek manusia dalam lingkungan kerjanya yang ditinjau secara anatomi, fisiologi, psikologi, engineering, manajemen, dan desain/ perancangan (Nurmianto, 2004). Dalam proses pengaplikasian, ergonomi berkaitan pula dengan optimasi, efisiensi, kesehatan, keselamatan, dan kenyamanan manusia di tempat kerja, rumah, tempat publik, dan sebagainya.

Ergonomi dalam International Ergonomic Association/IEA (2002), merupakan ilmu yang mempelajari manusia dengan elemen-elemen lain pada sistem dan pekerjaan yang menghasilkan teori, prinsip data dan metode untuk bisa membuat rancangan berupa suatu sistem yang optimal, dilihat dari sisi manusia dan kinerja. Ergonomi merupakan faktor yang penting, dikarenakan mempelajari mengenai sistem kerja tubuh manusia dan memberikan dampak balik berupa merancang atau mengevaluasi tugas, produk, pekerjaan, lingkungan, dan sistem kerja supaya dapat digunakan dengan nyaman sesuai kebutuhan, kemampuan, dan keterbatasan manusia. Prinsip ergonomi terbagi menjadi 5, yaitu:

1. Kegunaan (Utility)

Prinsip ini berarti produk yang dihasilkan bermanfaat bagi seseorang dalam mendukung aktivitas atau kebutuhan secara maksimal tanpa mengalami kesulitan atau masalah dalam kegunaannya.

2. Keamanan (Safety)

Prinsip ini berarti produk yang dihasilkan mempunyai fungsi yang bermanfaat tanpa beresiko membaha-yakan keselamatan yang dapat merugikan penggunanya.

3. Kenyaman (Comfortability)

Prinsip ini berarti produk yang dihasilkan mempunyai tujuan yang sesuai atau tidak 
menganggu aktivitas serta mendukung aktivitas seseorang.

4. Keluwesan (Flexibility)

Prinsip ini berarti produk yang dihasilkan dapat digunakan untuk kebutuhan dalam kondisi maupun fungsi ganda secara fleksibel.

5. Ketahanan (Durability)

Prinsip ini berarti produk yang dihasilkan harus tahan lama, awet, dan tidak mudah rusak jika digunakan untuk jangka waktu yang lama. (Nurmianto, 2004)

\section{Dimensi Produk}

Dimensi bentuk dibuat berdasarkan dari jumlah dan ukuran barang yang akan diletakkan di rak tersebut, sehingga dapat tercipta produk yang dapat menjawab kebutuhan dari user. Kegiatan teatrikal yang dilakukan oleh Komunitas Roode Brug Soerabaia membutuhkan cukup banyak property, antara lain senjata yang memiliki variasi ukuran dengan panjang $80 \mathrm{~cm}, 120 \mathrm{~cm}$, dan $140 \mathrm{~cm}$, karung goni, pakaian perang dan atribut lainnya, serta bambu runcing dengan ukuran $55-60 \mathrm{~cm}$.

\section{Kayu Pinus}

Kayu merupakan bagian batang atau cabang dari sebuah tanaman yang mengalami proses lignifikasi (pengayuan), kayu sendiri dibagi menjadi dua jenis yaitu softwood (kayu lunak) dan hardwood (kayu keras). Kayu lunak memiliki banyak contoh dan salah satunya adalah kayu pinus, yang merupakan salah satu kayu yang laku di kalangan pengrajin, karena memiliki struktur dan karakteristik yang baik. Kayu pinus sendiri memiliki jumlah lebih dari 20 jenis dengan nama spesies yang berbeda, terdapat dua jenis kayu pinus yang sering dipakai dan memiliki kualitas yang baik yaitu Pinus Radiata dan Pinus Merkusii. Pinus Radiata banyak tumbuh Australia, Amerika, Afrika dan sekitarnya, sedangkan kayu Pinus Merkusii ini banyak tumbuh di Asia Tenggara salah satunya di Indonesia, tepatnya di Pulau Sumatera di Gunung Kerinci atau Gunung Talang. Maka masyarakat di Indonesia banyak menggunakan kayu Pinus Merkusii.

Pohon Pinus Merkusii ini memiliki karakteristik pohon dengan ketinggian 24-25 meter, dengan diameter pohon hingga 1 meter. Kayu pinus memiliki karakteristik tekstur agak kasar, tidak berpori, memiliki saluran damar aksial tetapi sangat jarang, dan memiliki densitas $565-750 \mathrm{~kg} / \mathrm{m} 3$ pada MC $12 \%$. Serat dari kayu pinus merkusii ini lurus dan sama rata antara kayu gubal dan teras, dan memiliki warna kayu teras coklat kemerahan dan kayu gubal kuning keputihan.

Kayu Pinus Merkusii ini termasuk golongan kelas awet IV dan kelas kuat III. Kayu pinus sendiri membutuhkan perhatian lebih karena mudah terserang jamur (blue stains), maka kayu pinus yang sudah ditebang harus dikeringkan secepat mungkin. Kayu ini juga rentan terhadap perubahan suhu maka wajib menggunakan laminasi untuk mencegah jamur ataupun lapuk, ketika melakukan finishing juga harus memperhatikan mata kayu yang memiliki peluang terjadi tidak meratanya warna cat, terutama warna yang non-natural. Tetapi kayu pinus sendiri memiliki harga yang cukup terjangkau, dan mudah diproses karena seratnya yang halus membantu di dalam mempercepat proses finishing.

\section{E. Finishing}

Kayu memiliki pori-pori yang dapat dimasuki oleh air, minyak, debu, dan material lainnya. Masuknya material ini ke dalam kayu akan berpengaruh dalam kembang susut kayu, retak, melengkung atau berubahnya warna pada kayu. Selain itu juga produk kayu akan lebih mudah terserang organisme perusak seperti jamur atau serangga. Upaya dalam mengurangi hal ini dilakukan proses finishing.

Proses finishing kayu merupakan proses akhir atau penyempurnaan suatu produk, dengan cara melakukan pelapisan atau pengolesan resin atau suatu zat ke permukaan kayu, untuk memperoleh manfaatmanfaat tertentu. Finishing yang baik akan memberikan perlindungan permukaan kayu agar terhindar dari hal-hal berikut:

1. Korosi atau pengaruh bahan-bahan kimia yang merubah permukaan kayu.

2. Rusaknya permukaan karena terkelupas atau tergores.

3. Pengaruh cuaca seperti kelembaban, sinar matahari, dan perubahan bentuk.

4. Jamur-jamur pewarna dan pelapuk kayu.

5. Serangga yang sering melubangi dan memakan zat organik pada kayu (Yuswanto, 2000).

Beberapa manfaat lainnya yang bisa diperoleh dengan melakukan finishing yaitu, untuk menyamarkan kelemahan dari estetika kayu dalam hal warna dan tekstur. Tidak hanya memberikan nilai estetika lebih, tapi juga dalam hal ketahanan dalam perubahan suhu, cuaca, udara, serta memberikan ketahanan terhadap dan kewateran benturan, gesekan, pukulan dari perabotan lainnya. Hal ini dapat 
diartikan bahwa proses finishing kayu dapat menambah nilai estetika, ketahanan, dan keawetan dari kayu tersebut.

Finishing kayu sendiri memiliki beberapa metode pengaplikasian, salah satunya dengan metode brush atau kuas. Metode brush ini paling sering dilakukan oleh masyarakat, karena metode ini salah satu yang sederhana, terjangkau, dan mudah dilakukan. Tetapi dalam menjalankan metode ini dibutuhkan perhatian khusus dalam hal pemilihan kuas, untuk mendapatkan hasil terbaik disarankan untuk menggunakan kuas yang memiliki kualitas yang baik pula. Metode ini memiliki kekurangan yaitu, permukaan kayu yang telah di-finishing tidak akan sehalus dan serata metode spray atau poles.

Finishing kayu juga dipengaruhi oleh jenisjenis kayu yang digunakan. Hal ini dikarenakan tidak semua jenis kayu dapat diberikan finishing yang sama. Salah satu contohnya adalah kayu pinus yang kurang baik jika diberikan finishing kayu dengan warna yang tidak natural. Salah satu penyebabnya adalah banyaknya mata kayu dan kantong minyak yang terdapat pada permukaan kayu pinus. Mata kayu dan kantong minyak memiliki permukaan yang lebih keras daripada permukaan yang lainnya, yang akan menyebabkan penyerapan warna tidak maksimal dan berakibat tidak meratanya warna (transparansi).

\section{METODE PENELITIAN}

Metode penelitian yang digunakan yaitu penelitian kualitatif. Penelitian kualitatif adalah penelitian yang cenderung mengandalkan kekuatan indra peneliti yang bertujuan untuk memahami fenomena yang dialami oleh subjek penelitian misalnya perilaku dan tindakan secara holistik dan dengan cara deskripsi dalam bentuk kata-kata dan bahasa, pada suatu konteks khusus yang alamiah dan dengan memanfaatkan berbagai metode alamiah (Moleong, 2004).

Penelitian kualitatif ini dilakukan dengan pendekatan human centered design, merupakan salah satu pendekatan kreatif yang berfokus kepada pengguna yang akan menggunakan atau membutuhkan desain yang dirancang, sehingga prinsip ini bertujuan untuk memenuhi kebutuhan pengguna melalui solusi yang baru, khusus untuk pengguna tersebut (Ideo, 2015). Human centered design merupakan desain yang terinspirasi dari manusia dan berpusat pada manusia yang bertujuan untuk membangun empati yang mendalam dengan pengguna yang akan menggunakan produk. Dalam proses human centered design ini, terdapat tiga fase, yaitu:

1. Fase Inspirasi

Penulis belajar langsung dari pengguna, dengan cara membenamkan diri ke dalam hidup penggunanya, sehingga dapat memahami pengguna secara mendalam. Metode yang dapat dilakukan antara lain: body language, photo journal, the five whys, frame your design challenge, recruiting tools, interview, dan conversation starters.

2. Fase Ideasi

Memahami apa yang sudah dipelajari, kemudian mengidentifikasi peluang untuk desain dan membuat prototype dari solusi yang sudah ditemukan. Metode yang dapat dilakukan antara lain: brainstorm rules, bundle ideas, create a concept, design principles, mash-ups, dan frameworks.

3. Fase Implementasi

Solusi dari perancangan kemudian diwujudkan dan diuji oleh segmen pengguna yang ada. Metode yang dapat dilakukan pada fase ini antara lain: measure and evaluate, keep getting feedback, dan define success (Ideo, 2015)

Metode di dalam human centered design yang dapat digunakan dalam proses mendesain yang berpusat pada manusia, antara lain:

\section{Contextual design}

Merupakan sebuah pendekatan dan proses desain yang menggunakan metode berupa pengumpulan data lapangan etnografi namun prosesnya sangat terstruktur dan terdefinisi. Kemudian didukung dengan proses analisis yang mengintegrasikan konsep, produk, dan test dari pengalaman pengguna.

2. Lead user approach

Merupakan pendekatan yang melihat masalah dan kebutuhan yang belum umum secara produk, sehingga dapat memberikan solusi desain bahkan sebelum masalah tersebut menjadi kasus umum.

3. Emphatic design

Merupakan pendekatan desain untuk memberikan solusi dalam bentuk desain, dengan cara mengetahui perasaan pengguna terhadap sebuah produk yang sudah ada. Analisis yang dilakukan pada pendekatan ini seringkali dapat menciptakan inovasi baru di dalam desain, dan memberi solusi terhadap masalah yang bahkan tidak bisa diketahui oleh pengguna. 


\section{Participatory design}

Pendekatan desain yang melibatkan semua orang yang terlibat di dalam proyek, misal: pengguna, mitra, masyarakat, penduduk lokal, pengunjung. Kemudian menyumbangkan ide dalam segala proses, sehingga desain yang diciptakan efektif. Seringkali dilakukan melalui focus discussion group.

\section{Co-design}

Pendekatan desain yang berangkat dari konsep participatory design, namun tidak semua pihak diwajibkan untuk terlibat, hanya beberapa pengguna yang potensial, seperti ahli-ahli yang memahami desain, sehingga kerjasama yang terjalin bersifat kolaboratif dan terstruktur.

6. Applied ethnography

Tujuannya yaitu untuk memahami kehidupan sehari-hari sebuah kelompok manusia sebagai fenomena sosisal, dengan cara menjadi bagian dari kegiatan mereka (Steen, 2017).

Selanjutnya penelitian kualitatif dengan pendekatan pada human centered design ini menghasilkan data-data yang kemudian digunakan untuk proses perancangan produk bagi komunitas Roode Brug Soerabaia yang diimplementasikan dengan menggunakan metode design thinking. Design thinking merupakan sebuah metode dalam pemecahan masalah yang berpusat pada manusia yang menekankan empati, kolaborasi, kreasi bersama dan umpan balik untuk membuka kreativitas dan inovasi untuk merancang ide atau solusi yang layak dan dapat dilakukan. Tahapan perancangan di dalam metode design thinking, antara lain:

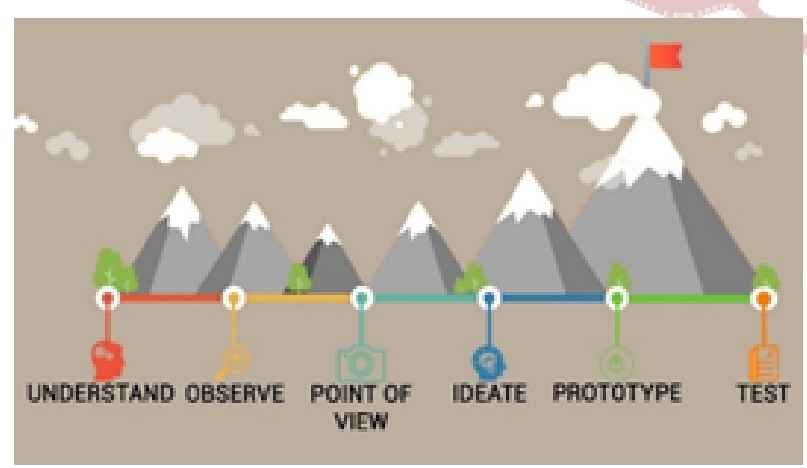

Gambar 1. Skema Design Thinking

(Sumber: Priscilla, 2019)

\section{a. Understand}

Tahap understand ini merupakan tahap pertama dalam proses design thinking. Tujuan dari tahap ini yaitu mengembangkan pengetahuan latar belakang melalui proses pengalaman yang dilakukan. Dalam tahap ini, proses pengumpulan data dilakukan dengan berbagai macam metode, antara lain menggunakan metode wawancara, observasi, dan dokumentasi kegiatan yang dilakukan. Pada tahapan ini, proses pencarian data literatur juga diperlukan sebagai referensi dan bahan untuk acuan di dalam proses perancangan produk.

\section{b. Observe}

Tahap observe merupakan tahap kedua dalam proses design thinking. Pada tahapan ini, pengumpulan data dilakukan dengan berinteraksi dan mengamati kegiatan yang dilakukan. Hasil data yang telah dikumpul-kan melalui proses wawancara dan observasi kegiatan digunakan sebagai penunjang kebutuhan untuk proses perancangan produk bagi komunitas. Hasil data kebutuhan ini kemudian dibutuhkan untuk mengembangkan rasa empati dan dianalisis melalui empathy map.

\section{c. Point of View}

Tahap point of view merupakan tahap ketiga dalam proses design thinking. Pada tahapan ini, masalah dan kebutuhan yang telah diperoleh dari dua tahapan sebelumnya dianalisis dan kemudian dijabarkan serta dikembangkan agar dapat menemukan solusi yang sesuai dengan kebutuhan dan berdampak pada pengalaman komunitas. Ideate

\section{d. Ideate}

Tahap ideate merupakan tahap keempat dalam proses design thinking dan merupakan komponen terpenting dari pemikiran yang ada. Dalam tahap ini, mulai mengeluarkan ide kreativitas dan membuatnya sebanyak mungkin. Ide yang dibuat dirumuskan ke dalam ide konsep yang sesuai dengan tujuan dan masalah yang harus diselesaikan. Setelah menemukan konsep perancangan, kemudian dilakukan proses sketsa secara manual dan membuatnya ke dalam berbagai alternatif yang berbeda-beda untuk mencari yang terbaik.

\section{e. Prototype}

Tahap prototype merupakan tahap kelima dalam proses design thinking. Dalam tahapan ini, alternatif yang terpilih kemudian dibuat ke dalam bentuk 3D render menggunakan software komputer. Berdasarkan hasil dari desain 3D, setelah desain akhir sudah selesai dibuat, maka dibuat gambar kerja dari produk yang kemudian digunakan di dalam proses pembuatan prototype produk skala 1:1. 


\section{f. Test}

Tahap test merupakan tahapan terakhir dalam proses design thinking. Dalam tahapan ini, dilakukan proses evaluasi dan pameran yang dilihat oleh tutor dan anggota komunitas yang diundang untuk menghadiri acara pameran yang diadakan oleh kampus (D-School, 2014).

\section{HASIL DAN PEMBAHASAN}

Komunitas Roode Brug Soerabaia, merupakan komunitas yang beranggotakan aktivis di bidang sejarah. Kegiatan dari komunitas ini beragam mulai dari teatrikal, berkunjung dan membersihkan bangunan bersejarah, mengadakan seminar tentang sejarah, dan masih banyak lagi

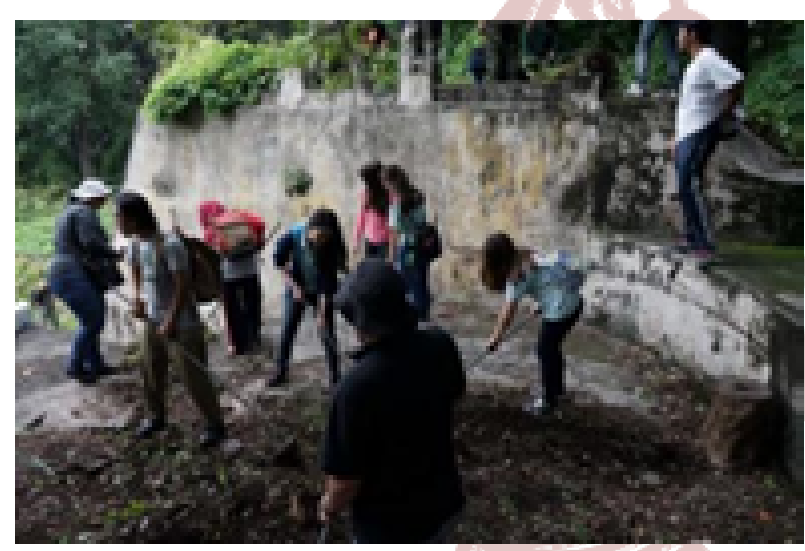

Gambar 2. Proses Kegiatan Membersihkan Benteng Kedung Cowek di Surabaya

(Sumber: Leony, 2019)

Kegiatan teatrikal yang dilakukan oleh komunitas merupakan highlight dari segala kegiatan yang dilakukan oleh mereka. Kegiatan teatrikal ini biasanya diadakan satu bulan sekali dan berlokasi di lapangan Tugu Pahlawan. Teatrikal ini membutuhkan properti seperti senjata-senjata, pakaian berperang, karung goni, kawat spiral, bambu runcing, dan masih banyak lagi. Properti yang dibutuhkan untuk melakukan teatrikal ini ada banyak, namun ruangan tempat menyimpannya kecil. Hal ini membuat munculnya sebuah masalah dan dibutuhkan suatu produk untuk menyimpan sekaligus dapat men-display properti teatrikal seperti senjata dengan rapi sehingga efektif dan efisien.
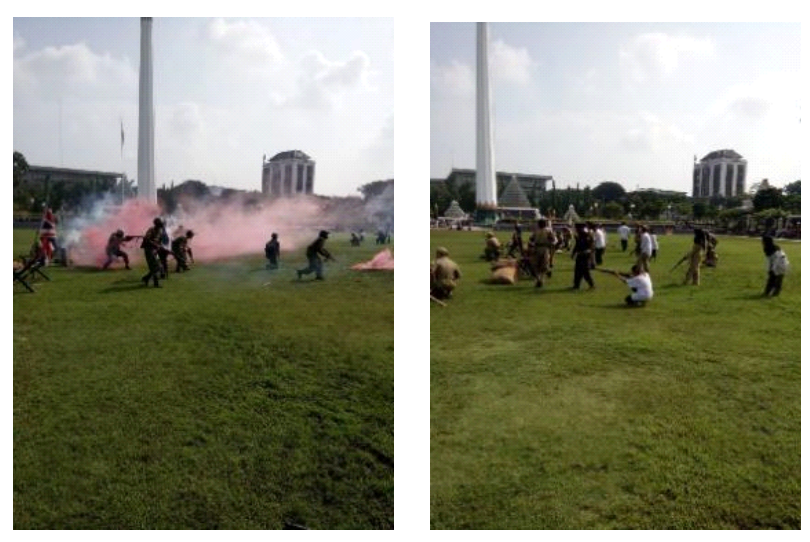

Gambar 3. Proses Kegiatan Membersihkan Benteng Kedung Cowek di Surabaya

(Sumber: Leony, 2019)

Berangkat dari latar belakang permasalahan ruang sempit dan membutuhkan penyimpanan yang efektif, maka muncul sebuah konsep perancangan produk yaitu "Bay to Bold - Surabaya History Booth to Fold". Produk ini berfungsi sebagai rak penyimpanan dan rak display untuk properti komunitas. Konsep ini dibuat agar produk dapat dilipat sehingga mudah dipindahkan dan multifungsi. Ketika dilipat, produk ini berbentuk balok. Sedangkan ketika dibuka, produk ini berbentuk limas. Bentuk limas saat produk dibuka ini terinspirasi dari bentuk tenda, yang merupakan tempat berlindung dan berobatnya para tentara pada zaman perang dahulu.

Desain produk ini didesain dengan menggunakan prinsip ergonomi yaitu kegunaan (utility) dan keluwesan (flexibility). Kegunaan dari produk ini ditujukan untuk memenuhi kebutuhan dari komunitas untuk menunjang kegiatan teatrikal yang dilakukan oleh mereka. Selain mendukung kegiatan teatrikal, produk ini juga dapat digunakan sebagai booth untuk keperluan pameran maupun sesi seminar tentang komunitas. Prinsip flexibility dalam desain produk ini yaitu produk dibuat multifungsi, dimana produk dapat dilipat dan dibuka yang berfungsi sebagai tempat penyimpanan dan display properti teatrikal seperti senjata. Selain itu fleksibilitas produk ini dapat dilihat juga dapat sistem penyimpanannya yang hemat space dan mudah disimpan di pojok ruang. 


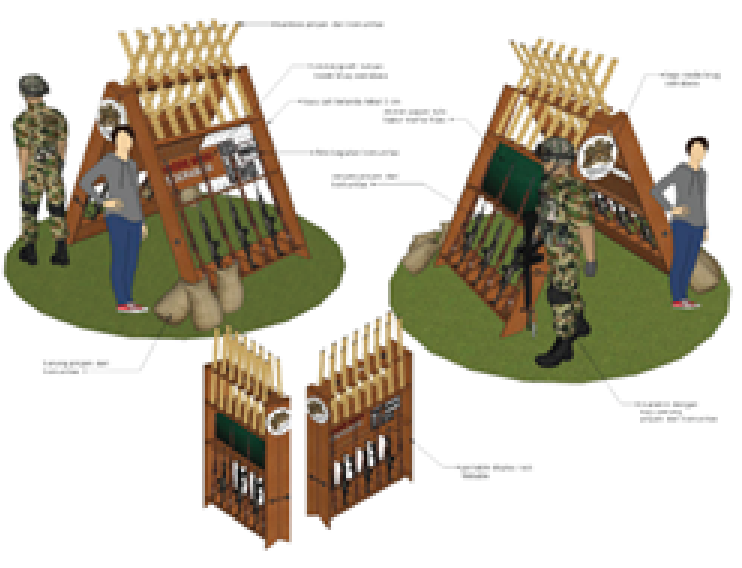

Gambar 4. Desain Akhir Perancangan Produk Rak (Sumber: Leony, 2019)

Setelah gambar 3D dari produk selesai dibuat, kemudian dibuat juga gambar kerja dari produk untuk bagian tampak dan bagian potongan agar dapat mempermudah di dalam pengerjaan produk asli dengan skala 1:1. Fungsi dari gambar kerja ini untuk menampilkan detail ukuran dan menjelaskan material yang digunakan dalam perancangan produk.

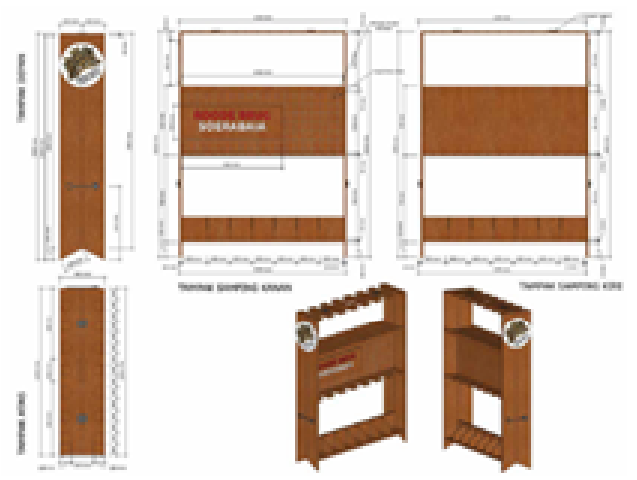

Gambar 5. Gambar Kerja Rak pada Posisi Terlipat (Sumber: Leony, 2019)

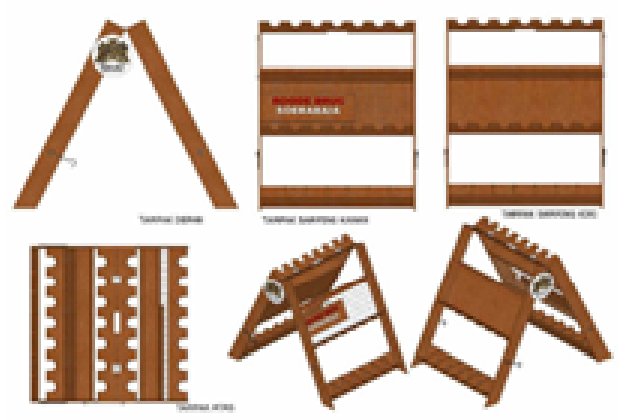

Gambar 6. Gambar Kerja Rak pada Posisi Terbuka (Sumber: Leony, 2019)
Selanjutnya setelah ditemukan desain akhir dari perancangan produk ini, kemudian dilakukan proses pembuatan produk asli skala 1:1. Produk ini dibuat dari kayu pinus merkusii dengan natural finishing berwarna walnut. Produk ini membutuhkan waktu pengerjaan hingga 2 minggu. Selain terbuat dari kayu pinus, produk ini juga dilengkapi dengan papan tulis berwarna hitam yang dapat digambar atau diberikan tulisan mengenai informasi seputar komunitas. Selain itu juga pada satu sisi diberikan kawat berukuran 2 $\mathrm{cm} \times 2 \mathrm{~cm}$ yang difungsikan sebagai tempat untuk meletakkan foto-foto kegiatan komunitas sebagai aksen dekoratif dan berfungsi untuk memperkenalkan komunitas kepada khalayak umum.

\section{s.}




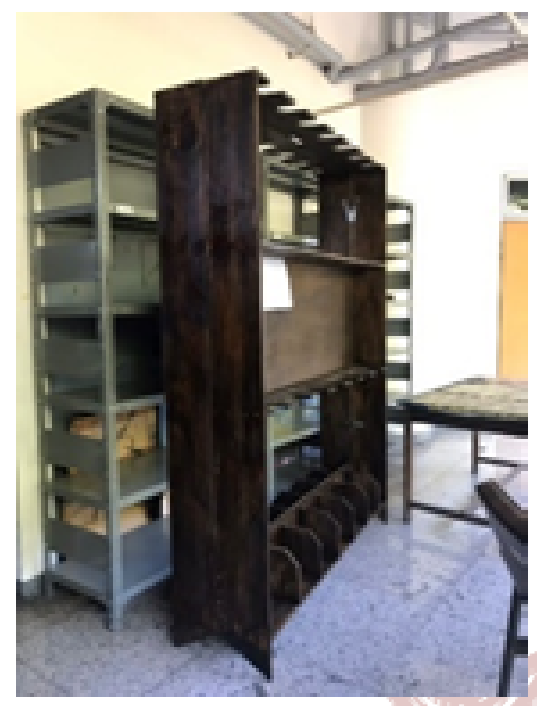

Gambar 9. Produk pada Posisi Terlipat (Sumber: Priscilla, 2019)

Produk yang telah jadi, dibawa ke area pameran yang diadakan di kampus Universitas Kristen Petra Surabaya. Produk ini dipamerkan dengan menggunakan properti teatrikal yang dipinjam dari komunitas Roode Brug Soerabaia dan dipercantik dengan manekin yang menggunakan pakaian perang yang mewakili rakyat Indonesia. Selain itu untuk menambah aksen Indonesia, maka ditambahkan juga bambu runcing yang merupakan simbolisasi dari perjuangan rakyat Indonesia pada saat melawan penjajah yang menggunakan senjata lengkap yang sudah canggih.
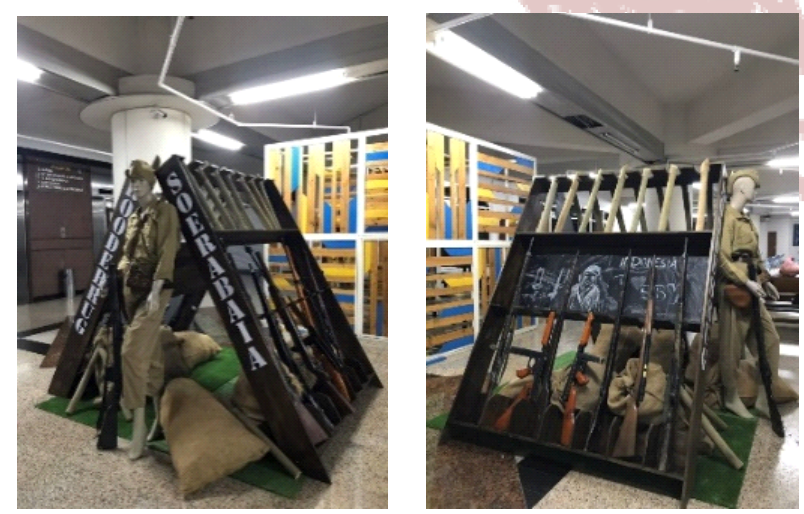

Gambar 10. Produk yang Sudah Di-styling untuk Pameran di Kampus (Sumber: Priscilla, 2019)

Pameran produk ini dilakukan selama kurun waktu 3 hari dengan mengundang para anggota dari komunitas Roode Brug Soerabaia untuk datang menghadiri pameran ini. Mereka menyambut baik hasil produk yang diberikan kepada mereka dan merasa sangat senang dengan desain yang telah dibuatkan.
Kemudian proses evaluasi pun dilakukan untuk memberikan masukan dan usulan perbaikan untuk produk desain yang telah dibuat. Produk yang ada telah menjawab permasalahan dan kebutuhan yang ada, namun masih membutuhkan pengembangan untuk penggunaan material yang berbeda. Kayu pinus yang menjadi material utama produk ini dirasa kurang cocok, karena sifat dan karakteristik kayu pinus yang merupakan golongan kelas awet IV dan kelas kuat III yang dapat dikatakan tingkatan kekuatan dan keawetannya kurang baik. Selain itu, kayu pinus juga merupakan kayu yang rentan terhadap perubahan suhu yang dapat menyebabkan tumbuhnya jamur (blue stain) pada permukaan kayu. Namun hal ini diatasi dengan pemberian finishing untuk menaikkan nilai ketahanan dari kayu pinus itu dari organisme perusak, pengaruh cuaca, dan jamur. Selain itu dikarenakan produk ini terlalu besar, maka material kayu pinus juga membuat produk ini menjadi berat sehingga sulit untuk dibawa kemana-mana namun tetap dapat dipindahpindahkan sesuai dengan kebutuhan aktivitas dari komunitas.

Hasil produk yang telah jadi didokumentasikan dan segala proses yang telah dilakukan mulai dari pendekatan awal dengan komunitas, mengikuti kegiatan komunitas, hingga kontribusi di dalam proses perancangan yang dapat bermanfaat bagi kegiatan komunitas Roode Brug Soerabaia sehingga dapat terus melestarikan sejarah dengan aksi-aksi kegiatan yang menarik dan terus dapat menginspirasi masyarakat umum.

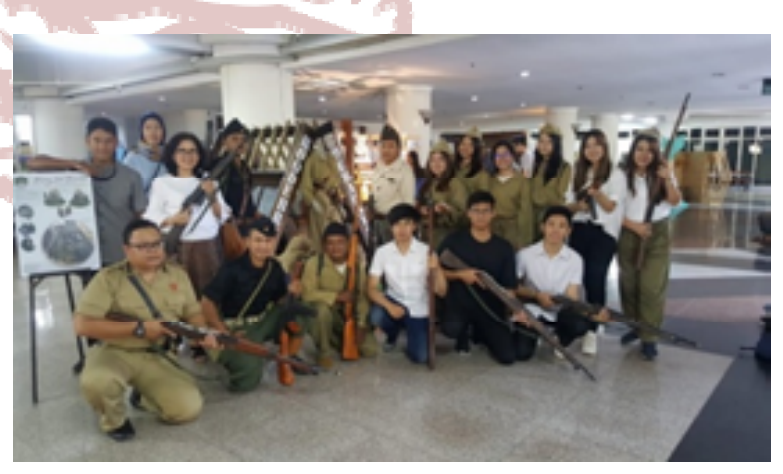

Gambar 11. Dokumentasi dengan Komunitas (Sumber: Priscilla, 2019)

\section{KESIMPULAN}

Implementasi konsep "Bay to Bold - Surabaya History Booth to Fold" menjawab rumusan masalah dimana anggota komunitas Roode Brug Soerabaia membutuhkan produk penyimpanan yang efektif dan efisien agar dapat disimpan dalam ruangan yang kecil. 
Konsep ini dibuat dengan model yang menarik yaitu sebuah rak display portable yang dapat dilipat. Rak ini dapat digunakan untuk menyimpan perlengkapan senjata dan digunakan sebagai properti untuk anggota komunitas mengadakan acara berupa seminar dan sesi sharing di dalam memperkenalkan komunitas kepada masyarakat umum.

Produk yang dibuat ini sudah baik dan menjawab permasalahan dan kebutuhan dari komunitas Roode Brug Soerabaia, namun masih membutuhkan pengembangan dan perbaikan dalam upaya untuk memaksimalkan fungsi dan kegunaannya. Desain ini diharapkan dapat memberikan semangat bagi anggota komunitas, agar terus melestarikan sejarah dan semakin memperkenalkan sejarah kepada generasi muda melalui cara-cara yang unik dan menarik.

\section{UCAPAN TERIMAKASIH}

1. Ady Setyawan, pendiri dari komunitas Roode Brug Soerabaia yang telah bersedia menjadi narasumber untuk membantu perancangan produk ini.

2. Anggota komunitas Roode Brug Soerabaia yang membantu dalam proses etnografi, empati, dan berkolaborasi dalam proses styling.

3. Dr. Dra. Sriti Mayang Sari, M.Sn., dosen pembimbing perancangan produk ini.

4. Dr. Laksmi K. Wardani, S.Sn., M.Ds., dosen pembimbing dan dosen mata kuliah seminar yang telah memberikan bimbingan dan masukan dalam jurnal ilmiah.

\section{DAFTAR PUSTAKA}

Ching, D.K. (2002). Ilustrasi desain interior. Jakarta: Penerbit Erlangga.

Harsokoesoemo, H.D. (2004). Pengantar perancangan teknik. Bandung: Institut Teknologi Bandung.

Hartiyono. (n.d.). Teknik finishing kayu. Malang: Departemen Bangunan PPPPTK BOE / VEDC Malang.

HPI. (2014). HPI Scholl of design thinking teaches user-friendly innovation. Germany: Hasso Platter Institut.
Ideo. (2015). The field guide to human-centered design. Canada: Ideo.org.

International Labour Office (ILO) \& International Ergonomics Association (IEA). (2000). Petunjuk praktis ergonomik, petunjuk yang mudah diterapkan dalam meningkatkan keselamatan dan kondisi kerja. Jakarta: Tim Penerjemah DK3N.

Kertajaya, H. (2008). Arti komunitas. Jakarta: Gramedia Pustaka.

Lapeantu, S. K., Hapid, A., \& Muthmainnah. (2017). Sifat mekanika kayu pinus (pinus merkusii jungh et de vriese) asal Desa Taende Mori Atas Morowali Utara Sulawesi Tengah. Warta Rimba, 5(1), 121-126.

Meita, W. (2009). Hubungan karakteristik anatomi dan kimia enam jenis kayu terhadap sifat Akustik kayu. Bogor. Jawa Barat: Institut Pertanian Bogor.

Moleong, L.J. (2004). Metodologi penelitian kualitatif. Bandung. Jawa Timur: PT. Remaja Rosdakarya.

Nurmianto, E. (2004). Ergonomi konsep dasar dan aplikasinya (Edisi pertama). Surabaya: Guna Widya.

Sjamsuddin, H. (1996). Metodologi sejarah. Jakarta: Depdikbud, Proyek Pendidikan Tenaga Akademika.

Steen, M., Kujit-Evers, L. \& Klok, J. (2007). Early user involvement in research and design projects -Areview of methods and practices. Vienna: EGOS Colloqium.

Tim Penyusun. (2018). Kamus besar bahasa Indonesia ed. 5. Jakarta: Balai Pustaka.

Yuswanto. (1999). Finishing kayu. Yogyakarta: Kanisius. 